\title{
SEPT6 Gene
}

National Cancer Institute

\section{Source}

National Cancer Institute. SEPT6 Gene. NCI Thesaurus. Code C97782.

This gene is involved in both cytokinesis and the organization of the actin cytoskeleton. 